\title{
Motivasi Dan Bimbingan Spiritual Untuk Sembuh Pada Penderita Stroke
}

\author{
Sirbini $^{1}$, Nur Azizah ${ }^{2}$ \\ IAIN Purwokerto
}

\begin{tabular}{l}
\hline \hline Article Info \\
\hline Article history: \\
Received Apr $09^{\text {th }}, 2020$ \\
Revised Sept $20^{\text {th }}, 2020$ \\
Accepted Sept $26^{\text {th }}, 2020$ \\
\hline
\end{tabular}

\section{Keyword:}

Motivasi Spiritual Bimbingan Spiritual Penderita Stroke

\begin{abstract}
ABSTRAK
Penelitian bertujuan untuk mendiskripsikan motivasi dan bimbingan spiritual untuk sembuh pada penderita stroke khususnya yang ada di Desa Padangsari Majenang Cilacap Jawa Tengah dengan berinteraksi dan dengan mengunjungi langsung penderita stroke. Hasil penelitian menunjukan bahwa penderita stroke menjadi lebih optimis sembuh dan mampu memiliki respon motivasi spiritual untuk sembuh. menunjukkan respon yang baik. Bentuk bimbingan spiritual yang diberikan kepada penderita stroke diantaranya motivasi, memberikan sugesti positif, support atau dukungan, dan edukasi dalam menjalankan ibadah selama sakit, seperti memberikan tuntunan tatacara shalat, tayamum beserta prakteknya, doa dan dzikir secara terus menerus, sehingga penderita stroke mampu mencapai motivasi spiritual untuk sembuh.
\end{abstract}

\section{Penulis:}

Sirbini

IAIN Purwokerto

Email: Chizbainalqolby134@gmail.com

\section{PENDAHULUAN}

Manusia merupakan makhluk ciptaan Allah SWT yang paling sempurna, karena mempunyai unsur-unsur jasmaniah dan rohaniah. Seringkali manusia menjalankan kehidupannya di dunia tidak selamanya memperoleh ketentraman dan ketenangan jiwa. Tapi sebaliknya, seiring dihadapkan pada berbagai persoalan yang timbul, baik fisik maupun psikis. Dengan kata lain, manusia menjalani hidup dengan penuh suka dan duka, kesenangan dan kesedihan silih berganti (A’la, 2017) .

Manusia hidup tidak terlepas dari penyakit yang bisa mengancam dan datang kapan saja, baik penyakit berat maupun ringan. Hal ini juga diperngaruhi oleh pola kesehatan maupun pola hidup manusia dalam meminimalisir penyakit yang bisa timbul dalam dirinya. Banyak penyakit fisik yang diderita oleh manusia, diantaranya: stroke, jantung, gagal ginjal, kanker, diabetes, AIDS, dan sebagainya.

Penyakit Stroke merupakan gangguan fungsi yang menyerang saraf pada otak sehingga bisa menyebabkan kelumpuhan pada saraf (deficit neurologic) yang dipicu adanya terganggunya aliran darah menuju bagian salah satu dari otak (Tamburian, Ratag, \& Nelwan, 2020). Stroke salah satu jenis penyakit yang jumlahnya mengalami peningkatan yang signifikan dari tahun ke 
tahun. Data World Stroke Organization menunjukan bahwa setiap tahunnya ada 13,7 juta kasus baru stroke, dan sekitar 5,5 juta kematian terjadi akibat penyakit stroke. Secara nasional, pravelensi stroke di Indonesia tahun 2018 berdasarkan diagnosis dokter pada penduduk umur $\geq$ 15 tahun sebesar 10,9\%, atau diperkirakan 2.120.362 orang. Provinsi Kalimantan Timur (14,7\%) dan di Yogyakarta $(14,6 \%)$ merupakan provinsi yang memiliki prevalensi tertinggi stroke di Indonesia. Sementara itu, Papua dan Maluku Utara memiliki prevalansi stroke terendah dibandingkan provinsi lainnya, yaitu 4,1\% dan 4,6\% (Aprianda, 2019).

Berdasarkan kelompok umur terlihat bahwa kejadian penyakit stroke terjadi lebih banyak pada kelompok umur 55-56 tahun $(33,3 \%)$ dan proporsi penderita stroke paling sedikit adalah pada kelompok umur antara 15-24 tahun. Laki-laki dan perempuan memiliki proporsi kejadian stroke yang hampir sama. Sebagian besar penduduk yang terkena stroke memiliki pendidikan tamat SD (29,5\%). Hal ini sama dengan karakteristik penyakit tidak menular lainnya. Sebagian besar penderita stroke bertempat tinggal di daerah perkotaan $(63,9 \%)$, sedangkan yang tinggal di pedesaan sebesar 36,1\% (Aprianda, 2019).

Serangan stroke pada manusia sering dianggap di masyarakat sebagai penyakit berat yang sulit disembuhkan dan merupakan bencana bagi penderita maupun keluarganya karena umumnya ditimbukan adanya kegagalan fungsi pada manusia sehingga mengakibatkan individu menjadi lumpuh dan sulit berkomunikasi tergantung tingkat kerentanan penyakitnya. Penderita stroke yang sudah didiagnosis oleh dokter biasanya akan mengalami ketakutan, kesedihan kecemasan, maupun putus asa menghadapi penyakit stroke yang dideritanya. Dampak pada ranah kehidupan juga terlihat pada biologis, psikologi, ekonomi, dan spiritual (Styana, Nurkhasanah, \& Hidayanti, 2016). Penyakit Stroke bisa membuat mengalami kehidupan yang berbeda dari kondisi sebelumnya. Hasil penelitian WHO bahwa sebanyak seperlima sampai dengan setengah dari penderita stroke menghadapi rasa putus asa, merasa tak berguna pada kemampuan diri, tidak punya optimisme hidup, lebih banyak berdiam diri, selera makan dan kemampuan bekerja menjadi menurun, yang semuanya disebabkan adanya kecacatan menahun. Namun, 25\% nya dapat bekerja seperti semula (A'la, 2017).

Penderita stroke juga memiliki problem psikospiritual (diluar problem fisiologis dan Psikologis). Problem spiritual yang dialami oleh penderita stroke juga tidak bisa disepelekan seperti dengan problem fisik. Kesadaran psikopsiritual ini yang perlu kembangkan dalam diri penderita dan keluarga (Dharma, Parellangi, \& Rahayu, 2020). Problem spiritual yang ditemukan dalam riset ini, seperti: melalaikan kewajiban menjalankan shalat lima waktu karena kesusahan secara fisik, ketidaktahuan pengetahuan penderita tentang cara shalat saat sakit.

Kemampuan menerima kondisi disabilitas pada penderita stroke merupakan kunci untuk mengurangi cemas dan mencegah depresi. Beberapa penelitian membuktikan intervensi berupa komitmen dan penerimaan diri dapat menurunkan tanda dan gejala cemas dari level moderat menjadi ringan. Penerimaan diri berperan penting dalam meningkatkan kemampuan penderita beradaptasi dan mempertahankan kualitas hidup yang optimal. Jika penderita mampu menerima kondisi yang dialaminya dan tidak larut dalam kesedihan, maka motivasi penderita untuk sembuh akan meningkat (Dharma et al., 2020).

Berdasarkan dampak yang ditimbulkan oleh penyakit stroke diatas, maka dalam riset ini sangat lah penting untuk diuraikan beberapa langkah-langkah motivasi spiritual dan bimbingan spiritual sebagai salah satu usaha preventif dari timbulnya penyakit kejiwaan maupun dampak yang lainnya melalui pendekatan spiritual, sehingga kualitas pelaksanaan maupun pengamalan ibadah seperti: sholat, berdoa, dan lain sebagainya masih bisa dilakukan dengan baik walaupun dalam kondisi sakit dan diharapkan dapat memberikan energi positif meraih kesembuhan atas ridho Allah.

Spiritualitas sebagai manusia universal dan fundamental kualitas mencari makna, kesejahteraan, dan kedalaman melalui koneksi dengan diri sendiri, orang lain, dan alam semesta, dan agama sebagai sistem kepercayaan, nilai, dan praktik yang dilembagakan yang berorientasi 
pada masalah spiritual dan ditransmisikan dari waktu ke waktu oleh komunitas.(Haia, Franklina, Parkb, DiNittoa, \& Aurelio, 2019)

Keterlibatan spiritual dan keagamaan berkontribusi terhadap kualitas hidup dalam hal mengurangi gejala depresi dan kecemasan, menurunkan tingkat bunuh diri dan penyalah gunaan obat. Spiritual juga digunakan untuk mengatasi kesulitan sehari-hari sebagai metode koping yang memberi pengaruh positif, semangat, harapan dan kepuasan hidup yang besar. Bimbingan spiritual adalah proses yang dilakukan dalam pemberian bantuan kepada individu supaya memiliki kemampuan untuk mengembangkan fitrahnya sebagai makhluk beragama (homo religius), berperilaku sesuai dengan ajaran dan nilai-nilai agama (mempunyai akhlak mulia), dan mampu mengatasi permasalahan yang dialami dalam kehidupannya melalui proses pemahaman, keyakinan diri, maupun pelaksanaan ibadah dan ritual agama yang dianutnya (Sitepu, Asrizal, \& Lufthiani, 2019).

Setiap manusia dalam keadaan apapun baik ketika sehat maupun sakit baik secara fisik, psikologis harus selalu memohon pertolongan Allah, sehingga ketika menjalani kehidupan dapat meraih keberkahan dalam hidup, diberikan kesehatan serta ketenangan (A'la, 2017).

Motivasi menurut Az-Zahrani merupakan energi dalam diri manusia yang menghasilkan kekuatan untuk melakukan aktivitas. Motivasi dibagi menjadi dua bagian penting yaitu motivasi utama atau motivasi psikologi dan motivasi kejiwaan atau spiritual. Motivasi utama atau motivasi psikologi adalah motivasi fitrah manusia yang menjadi tabiat dan dibawa manusia sejak dilahirkan, motivasi ini berkaitan dengan bentuk fisik. Sedangkan motivasi kejiwaan atau spiritual berkaitan dengan kebutuhan manusia secara kejiwaan atau spiritual tanpa adanya interaksi langsung secara biologis, namun lebih kearah kebutuhan manusia untuk berkembang dengan interaksi sesama manusia dan kebutuhan yang berkaitan dengan aspek spiritualitas pada diri manusia (Suseno, 2012).

Motivasi spiritual seorang muslim ada 3 bagian yaitu: Motivasi akidah, motivasi ibadah, dan motivasi muamalah. Motivasi akidah merupakan bentuk keyakinan dalam hidup, yaitu keyakinan bersumber dari hati, motivasi ibadah merupakan motivasi yang tidak dimiliki dan dilakukan oleh orang yang tidak memiliki agama, seperti sholat, doa, dan puasa. Sedangkan motivasi muamalah merupakan pemenuhan dan manajerial dalam mencukupi kebutuhan manusia, baik berupa kebutuhan primer (pokok), sekunder (tambahan atau kesenangan) disertai kewajiban peningkatan kinerja dan kebutuhan tersier (kemewahan) yang dilarang oleh Islam (Suseno, 2012).

Spiritualitas penderita stroke fokus pada penerimaan diri atas sakitnya. Motivasi spiritual dengan memberikan penguatan dan dukungan untuk mempunyai harapan kesembuhan, dimana harapan sebagai bentuk bagian dukungan sosial. Peran orang lain dilingkungannya untuk memberikan dukungan sepenuhnya serta mengingatkan kepada penderita stroke untuk selalu berfikir positif atas cobaan yang terjadi disertai dengan tetap menjalankan ibadah dan mendekatkan diri kepada Allah sehingga senantiasa mendaptkan ketenangan selama sakit sehingga bisa memberikan energi baru untuk cepat sembuh (Styana et al., 2016).

Tujuan bimbingan konseling salah satunya yaitu membantu klien dalam penyembuhan diri, maka semua jenis sumber daya penyembuhan harus dilihat termasuk bagian spiritualitas dalam agamanya, pengembangan dengan perspektif spiritual dalam proses konseling dengan menggunakan paradigma pendekatan iman, takwa maupun akhlak sehingga mewujudkan manusia bisa hidup lebih bahagia. Zeiger dan Lewis terdapat 2 tipe bimbingan yaitu. Pertama. Bimbingan dengan pendekatan Eksplanatori yaitu bimbingan berbasis agama yang dilihat dari pengaruh eksternal bagi klien dan berupa kepercayaan ataupun tindakan yang bersifat irasional. Kedua. Bimbingan dengan pendekatan Deskriptive adalah bimbingan dengan melihat penghargaan yang diberikan oleh agama dan kepercayaan yang bisa terjadi pada individu dapat menolong dirinya untuk berkembang dan berubah (Satriah, 2008). 
Maslow mengatakan bahwa individu terlebih dahulu memenuhi kebutuhan primer (fisiologis) sebelum mengarahkan perilaku dalam memenuhi kebutuhan transendeltal yang lebih tinggi (spiritual). Motivasi spiritual adalah keyakinannya yang berhubungan erat atas eksistensi Sang Pencipta. Contohnya ketika individu percaya adanya Allah Sang Pencipta, maka spiritual individu akan menunjukkan hubungan vertikal maupun horisontal tentang keharmonisan atau keselarasan dengan lingkungan dunia luar dirinya, untuk berjuang menjawab dan meningkatkan kekuatan individu ketika sedang dihadapkan pada keadaan stress, emosional, mempunyai penyakit fisik, atau menghadapi kematian (Umah \& Irawanto, 2019).

Piedmont membagi spiritualitas atas tiga aspek perilaku spiritual yang dikembangkan Piedmont yaitu Spiritual Transcendence Scalae (STS) sebagai berikut: Pray Fulfillment (pengalaman Ibadah), adanya perasaan bahagia dan gembira yang diwujudkan atas keterlibatan diri terhadap unsur realitas transenden. Universality (universalitas) berupa unsur keyakinan yang muncul dalam kesatuan hidup di alam semesta (nature of life) yang muncul dalam kehidupan dirinya. Connectedness (keterkaitan), yakni sebuah keyakinan dimana individu bagian dari realitas kelompok manusia yang lebih besar yang bisa melampaui kelompok generasi tertentu (Ridho, 2018).

Pemberian motivasi dan bimbingan spiritual sangat penting dilakukan sebagai bagian layanan maupun edukasi yang bisa diberikan dalam memberikan dukungan kesembuhan bagi penderita stroke maupun penderita penyakit yang lain. Keadaan spiritual bagi penderita penyakit stroke dalam riset ini bukan lagi menjadi persoalan yang sederhana, melainkan sudah semestinya menjadi persoalan yang mendalam karena dalam keadaan lumpuh setengah badan bagian kanan dan bicara yang kurang jelas, menjadikan penderita sulit untuk beraktivitas normal seperti sediakala. Hal ini, menjadikan sebuah alasan untuk dapat melakukan aktifitas maupun dalam hal peribadatan, seperti halnya sholat lima waktu, bersuci dari hadast dan berdoa/dzikir. Dari latar belakang tersebut, maka dalam riset ini peneliti ingin mempelajari lebih dalam mengenai motivasi spiritual untuk sembuh pada penderita stroke di Desa Padangsari Majenang Cilacap Jawa Tengah.

\section{METODE}

Subjek dalam penelitian ini adalah penderita stroke dengan keadaan lumpuh setengah badan bagian kanan mulai dari bagian tangan kanan sampai ujung kaki bagian kanan. Penderita dengan jenis kelamin laki-laki ini berusia 61 tahun yang sudah menjalani masa sakitnya selama 7 bulan. Subjek memiliki karakteristik tertentu secara spiritual dalam menghadapi sakit yang dideritanya, seperti: kurangnya rasa ingin untuk sholat lima waktu, kesusahan dalam bersuci dari hadast dan pesimis ketika berdoa meminta kesembuhan terhadap Allah SWT. Kondisi emosi yang tidak stabil seperti, seringnya mengeluh dan merasa bosan akan sakit stroke yang dideritanya. Serta kurangnya pengetahuan tentang kaifiyah atau tatacara sholat, bersuci bagi penderita stroke. Oleh karena itu, penelitian ini memilih subjek tersebut untuk dapat menumbuhkan pemikiran positif dalam menghadapi sakit yang dideritanya, serta memberikan edukasi tentang kaifiyah/tatacara beribadah. Sehingga dapat melakukan aktifitas peribadatan yang sesuai ajaran Islam.

Peneliti memilih studi deskriptif karena data yang nanti diperoleh oleh peneliti berasal dari wawancara, observasi, dan dideskripsikan dengan bahasa yang jelas dan tersusun secara sistematis. Dalam menggali data peneliti lakukan secara mendalam yaitu datang langsung kepada informan dan lokasi penelitian (A'la, 2017).

Metode pengumpulan data yang dilakukan adalah dengan wawancara, dengan melakukan komfirmasi melalu percakapan atau tanya jawab secara langsung. Selain wawancara, peneliti juga menggunakan metode observasi, yaitu melakukan pengamatan langsung untuk mendapatkan keadaan dan data penelitian dalam kondisi yang sebenarnya (Sugiyono, 2009). 
Peneliti juga menggunakan dokumentasi dalam pengambilan data. Di dalam penelitian ini dokumentasi yang dipakai adalah data-data yang berhubungan dengan subyek yang diteliti yaitu dokumen tentang dilakukannya motivasi spiritual dan praktek ibadah seperti bimbingan shalat lima waktu (Sugiyono, 2009). Hasil pengumpulan data melalui cara dokumentasi ini, dicatat dalam lampiran dokumentasi.

Data yang didapatkan dan sudah terkumpul kemudian dianalisis. Analisis data melakukan pengorganisasian data penelitian yang ada kemudian disusun dengan sistematis sesuai dengan pola yang sudah ditetapkan untuk mempermudah melakukan pembahasan dan kesimpulan yang hasilnya bisa di pahami untuk peneliti sendiri maupun orang lain (A'la, 2017).

\section{HASIL DAN PEMBAHASAN}

Peneliti menemukan terdapat 10 kategori yang berhubungan dengan motivasi dan bimbingan spiritual untuk sembuh pada penderita stroke di desa Padangsari Majenang Cilacap Jawa Tengah. Kategori ini dikelompokan berdasarkan hasil wawancara dan observasi yang telah peneliti lakukan. Sepuluh kategori tersebut kemudian membentuk tiga pola, yaitu:

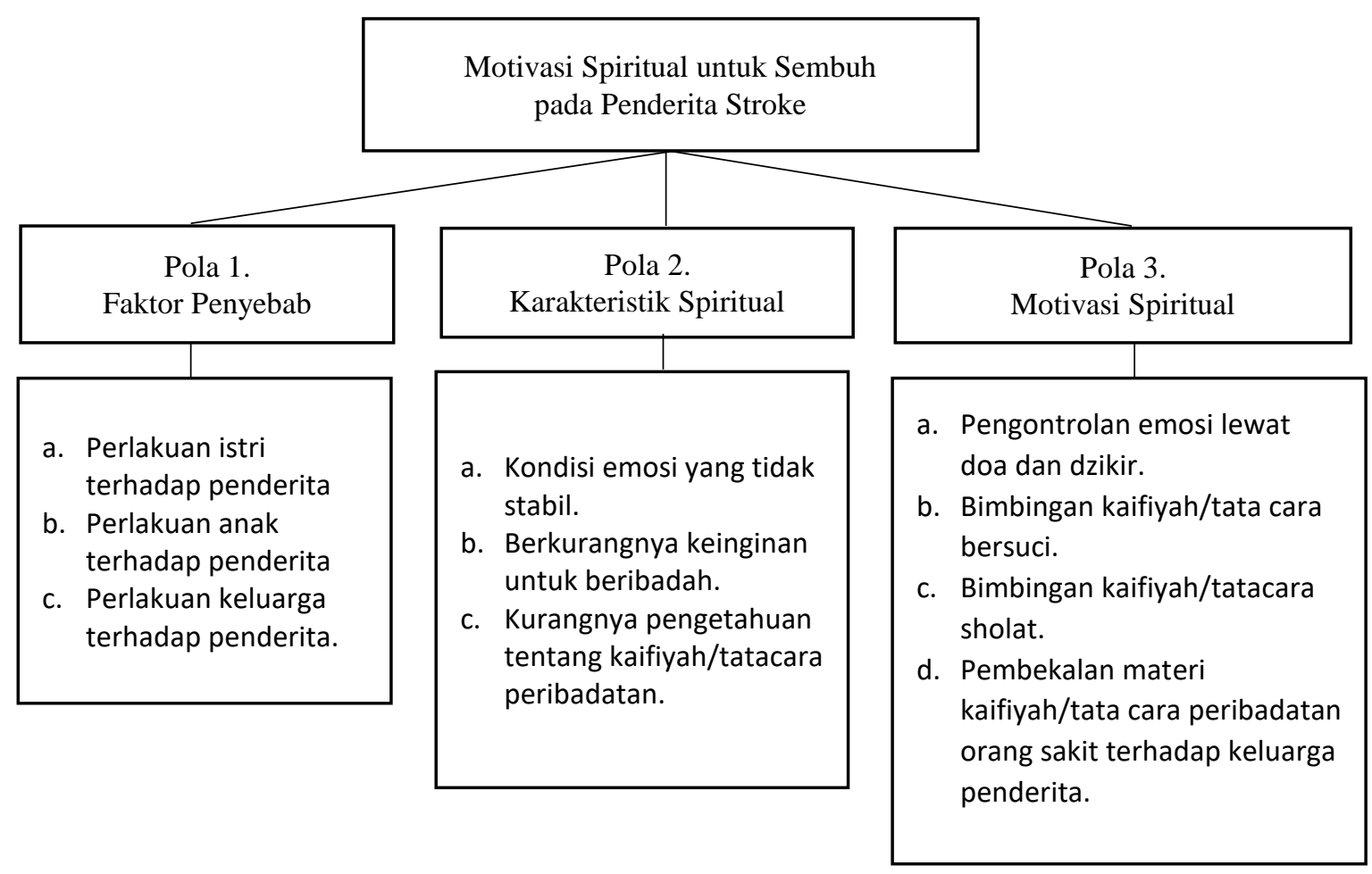

\section{Gambar 1. Hasil Penelitian}

1. Faktor penyebab motivasi spiritual untuk sembuh pada penderita stroke

a. Perlakuan istri terhadap penderita

Kesabaran seorang istri dalam merawat penderita stroke, menjadikan motivasi tersendiri bagi penderita untuk sembuh.

b. Perlakuan anak terhadap penderita

Edukasi yang dilakukan oleh peneliti tentang kaifiyah/tatacara peribadatan bagi penderita strok kepada anak penderita, menjadikan kebahagian tersendiri bagi penderita yang mendapatkan perhatian dari anak-anaknya.

c. Perlakuan keluarga terhadap penderita. 
Berkumpulnya keluarga menjadikan kehangatan tersendiri bagi penderita untuk dapat menceritakan keadaan.

2. Karakteristik motivasi spiritual untuk sembuh pada penderita stroke

a. Kondisi emosi yang tidak stabil.

Penderita stroke mengalami distress spiritual, dimana penderita mengalami kerusakan kemampuan dalam menghubungkan dan menginternalisasi arti dan tujuan hidup bagi diri sendiri maupun orang lain.

b. Berkurangnya keinginan untuk beribadah.

Kondisi penderita yang terkena stroke menjadikan sebuah alasan pokok untuk tidak melakukan ibadah seperti sholat lima waktu dan bersuci dari hadast.

c. Kurangnya pengetahuan tentang kaifiyah/tatacara peribadatan.

Kurangnya pengetahuan tentang kaifiyah/tatacara peribadatan menjadikan penderita tidak bisa melakukan peribadatan dengan sempurna.

3. Motivasi dan bimbingan spiritual untuk sembuh pada penderita stroke

a. Pengontrolan emosi lewat doa dan dzikir.

Kondisi emosi yang kurang stabil pada penderita stroke karena kurangnya berharap pada Allah SWT mengarahkan peneliti dalam riset ini untuk selalu mengajak berdoa dan berdzikir kepada Allah SWT dengan tujuan ketentraman batin bagi penderita stroke, sehingga dapat mengontrol emosinya dengan baik.

b. Bimbingan kaifiyah/tata cara bersuci.

Kurangnya pengetahuan tentang tata cara bersuci bagi penderita seperti belum mengetahui cara tayamum yang benar dalam keadaan sakit yang dideritanya menjadikan peneliti melakukan bimbingan untuk dapat menambah pengetahuan tentang tata cara bersuci yang benar bagi penderita stroke.

c. Bimbingan kaifiyah/tata cara sholat.

Kurangnya pengetahuan tentang tata cara sholat bagi penderita seperti belum mengetahui cara takbirotul ikhrom dengan satu tangan yang lumpuh, melakukan gerakan sholat dengan duduk dalam keadaan kaki yang belum bisa untuk berdiri, menjadikan peneliti melakukan bimbingan untuk dapat menambah pengetahuan tentang tata cara sholat yang benar bagi penderita stroke.

d. Pembekalan materi kaifiyah/tata cara peribadatan orang sakit terhadap keluarga penderita.

Memberikan pembekalan tentang tata cara peribadatan bagi orang sakit terhadap keluarga penderita, menjadikan penelitian ini sebagi dorongan tersendiri untuk dapat meningkatkan konsistensi penderita dalam melakukan peribadatan sesuai tuntunan Islam.

Berdasarkan hasil data yang diperoleh selama proses penelitian berlangsung, peneliti menemukan tiga pola yang membentuk 10 kategori terkait dengan motivasi dan bimbingan spiritual untuk sembuh pada penderita stroke melalui wawancara dan observasi. Penyakit stroke merupakan penyakit kronis. Namun, memilki efek yang signifikan pada aspek psikologis, sosial, dan spiritual penderitanya (Styana et al., 2016). Kebutuhan spiritual dapat meningkatkan optimis, dukungan sosial, harapan, mengurangi depresi dan kecemasan, serta mendukung perasaan relaksasi dikarenakan penderita stroke memiliki masalah yang kompleks (bio-psiko-sosiospiritual) (Styana et al., 2016).

Respon spiritual manusia dibagi dua, yaitu respon spiritual adaptif, akan menunjukan sikap positif pada diri sendiri dan Tuhan dalam berbagai keadaan dan kondisi walaupun menderita dan sedih sekalipun. Respon spiritual adaptif terdiri dari harapan realistis, tabah, sabar, serta 
mengambil hikmah (Nursalam, K, Misutarno, \& S, 2008). Sedangkan respon spiritual maladaptif adalah seperti distress spiritual. Distress spiritual adalah kerusakan kemampuan diri individu dalam mengalami perjalanan hidup serta mengintegrasikan arti maupun tujuan hidup diri sendiri, orang lain, maupun dengan seni, musik, literatur, bahkan alam dan kekuatan yang punya kekuatan lebih besar dari dirinya. Munculnya gangguan jiwa sering dihubungkan dengan kondisi kegagalan otak yang berfungsi kompensasi dalam menghadapi stresor sehingga bisa muncul perilaku maladaptif bahkan terjadi kegagalan fungsi kompensasi yang ditandai munculnya gangguan perilaku sehari-hari yang secara fisik, psikologis, sosial maupun spiritual. Perilaku tersebut bisa diperkirakan mempengaruhi kemampuan seseorang dalam kebutuhan spiritualnya yang akhirnya bisa terjadi distresspiritual, dimana kalau kasus depresi menunjukkan individu kehilangan motivasi untuk memenuhi kebutuhan juga berupa kebutuhan spiritual (Styana et al., 2016).

Setiap orang akan dihadapkan pada suatu aktivitas yang penuh tantangan dalam hidupnya, banyak orang yang tidak menyadarinya ketika menghadapi tantangan hidup, individu bisa menghadapi hambatan berat yang muncul dalam dirinya sendiri, seperti munculnya pikiranpikiran negatif yang punya kemauan yang lemah, bersikap pesimis, serta tergantung pada orang lain. Mengoptimalkan pikiran yang postif menjadi salah satu solusi untuk membentuk sikap optimis, menyukai tantangan, mencari solusi, maupun mempunyai kemauan kuat (Tanti Suryawantie, 2019).

Berdasarkan temuan penelitian terkait motivasi spiritual untuk sembuh bagi penderita stroke, pelaksanaan bimbingan kaifiyah/tata cara peribadatan bagi penderita ternyata dapat menumbuhkan rasa senang karena telah mendapatkan sedikit arahan untuk dapat melakukan cara ibadah yang sesuai dengan ajaran Islam. Kemudian dengan adanya bimbingan spiritual seperti doa dan dzikir secara terus menerus dengan keadaan yang tenang dan ikhlas, penderita bisa menngembangkan persepsi dan motivasi positif dengan mengharapkan pertolongan Allah SWT.

Secara etiologi (penyebab) timbulnya peyakit ada lima, yaitu: 1) pola pikir, 2) pola makan, 3) pola laku, 4) pola lingkungan (misal radiasi), serta 5) kehendak Allah SWT. Sumber penyakit dinataranya: faktor tidak ikhlas dan sombong yang selalu muncul dihati. (Sholeh, 2007).

Temuan penelitian terkait motivasi spiritual untuk sembuh bagi penderita stroke, penderita merasa terbawa pada suatu kondisi emosional yang stabil. Penderita merasa lebih rileks dan kondisi psikologi menjadi lebih tenang. Penderita yang melakukan doa dan dzikir sering marahmarah, namun setelah melaksanakan doa dan dzikir secara terus menerus merasa lebih tenang dan tidak mudah marah.

Temuan lain dalam penelitian bagi penderita stroke ini juga memiliki problem yang kompleks (bio-psiko-spiritual). Sakit fisik yang diderita tidak berefek tunggal, namun berintegrasi dengan aspek lainnya dalam diri pasien. Deskripsi problem tersebut yaitu meliputi problem biologis atau fisik, stroke yaitu hilangnya sebagian fungsi otak yang terjadi secara mendadak akibat sumbatan atau pecahan pembuluh darah otak. Hal ini berakibat pada gerakan terbatas organ tubuh sebelah kanan pada penderita. Problem psikologis, stroke adalah penyakit akut yang datang tiba-tiba, dikibatkan adanya hipertensi yang sering muncul, dan mencapai puncaknya adalah tensi darah naik. Problem sosial, bagi penderita pribadi harus memutuskan sementara komunikasi dengan keluarga dan tetangga, meninggalkan kebiasaan yang dilakukan sperti menghadiri majelis taklim dan berkunjung sanak saudara. Penderita belum merasa siap meninggalkan aktivitas umum sebagaimana manusia sehat sebagaimana umumnya, ketika biasanya bisa bebas berkumpul di lingkungannya maupun keluarga, maka harus istirahat di tempat tidur, yang biasanya bekerja sekarang menjadi terbatas aktivitas, dan problem spiritual, penderita diarahkan tetap menjalankan shalat meskipun dengan tayamum atau bimbingan keluarga serta penderita menjadi terganggu pada tingkat keyakinannya maupun pengamalan kaifiyah shalat yang dikerjakan. Karena bagi penderita terbiasa mengambil air wudhu dengan tanpa hambatan, dan sekarang harus dengan bertayamum. Penderita bisa sempurna mengerjakan 
shalat dari awal mulai takbir sampai akhir salam, sekarang harus berbaring atau duduk. Penderita biasa terbebas dari sesuatu hadast dan najis sekarang harus berdekatan dan bersentuhan dengan kantong urien, itulah yang membuat penderita menjadi ragu dari sisi kekuatan spiritualnya.

Agama maupun spiritualitas, berkaitan dengan pencarian makna. Agama berkaitan dengan perilaku spiritualitas yang sakral atau transenden dan dimediasi oleh sistem keyakinan dan praktik yang berhubungan dengan pengalaman manusia (Lazenby, 2018). Pengalaman spiritual yang dikaitkan dengan peristiwa dan pengalaman ini tidak selalu dianggap spiritual semata, namun dalam pelaksanaan ibadahnya.(Lifshitza, Elkc, \& Luhrmann, 2019)

Problem biologis atau sakit fisik yang ringan sekalipun tetap berdampak terhadap aspek psiko-sosio-spiritual pasien. Apalagi sakit yang terbilang parah seperti penyait kronis stroke akan berakibat signifikan terhadap aspek lainnya. Penderita stroke harus berjuang untuk menumbuhkan penerimaan diri terhadap penyakitnya. Respon dan reaksi sebagian pasien bergantung pada pemahaman individu terhadap penyakitnya dan persepsi penderita.

Penderita stroke juga melewati beberapa tahap atau fase kehilangan sampai pada akhirnya individu mampu menerima keadaan dirinya. Tahap atau fase kehilangan tersebut yang pertama, Fase Denial (pengingkaran), reaksi individu pada fase ini adalah shock, tidak percaya atau menolak kenyataan. Fase anger (marah) dimulai dengan adanya kenyataan yang terjadi pada dirinya. Reaksi yang ditunjukan antara lain perilaku agresif, bicara kasar, menolak pengobatan, dan menuduh perawat dan dokter tidak handal. Ketiga, Fase Bargaining (tawar-menawar), apabila individu telah mampu mengungkapkan rasa marahnya secara intensif, maka individu akan maju pada fase tawar menawar. Keempat, Fase depression (depresi), individu pada fase ini sering menunjukan sikap antara lain menarik diri, tidak mau bicara, menunjukan ungkapanungkapan yang menandakan keputusasaan dan perasaan tidak berharga. Dan kelima, Fase acceptance (penerimaan), fase ini berkaitan dengan reorganisasi perasaan kehilangan. Individu telah menerima keadaan dirinya yaitu menerima penyakit yang dideritanya sekarang. Jika individu mampu menyelesaikan fase-fase sebelumnya dengan tuntas maka akan lebih mudah masuk dalam fase penerimaan diri (Styana et al., 2016).

Dengan adanya beberapa fase pada penderita stroke, maka penderita akan menampakan respon spiritual yang adaptif dan maladaptif. Respon yang ditunjukan akan menentukan tingkat kebutuhan penderita terhadap motivasi spiritual untuk sembuh yang akan diberikan oleh peneliti. Respon spiritual yang adaptif akan menunjukan sikap yang positif terhadap diri sendiri dan Tuhan dalam berbagai kondisi meskipun menderita dan sedih sekalipun. Sebaliknya respon spiritual maladaptif menunjukan sikap negatif terhadap diri sendiri, orang lain dan juga Tuhan atas apa yang dialami.

Penelitian ini menunjukan bahwa penderita memiliki respon spiritual maladaptif seperti gampang meluapkan emosi pada orang lain, merasa penyakit sebagai hukuman, tidak mau menerima diri sendiri, dan enggan untuk melakukan peribadatan dengan alasan sakit yang dideritanya. Kondisi penderita yang mengalami respon spiritual maladaptif sangat memerlukan bantuan spiritual yang dapat menumbuhkan rasa optimis, selalu sabar dalam menghadapi sakitnya.

Adapun materi yang disampaikan dalam penelitian ini secara umum ada 5 materi, diantaranya adalah khusnudzon, Sabar, Doa, Kaifiyah Sholat dan Kaifiyah bersuci dari hadast dan najis. Materi yang diberikan lebih mengarahkan pemahaman dari sisi sikap untuk menerima kondisi sakit. Tetap percaya dengan Allah tidak mendzalimi hamba-Nya. Kemudian, dengan pendekatan hati, untuk mencoba untuk menyelami perasaan penderita.

Temuan penelitian dalam memberikan sebuah materi terhadap penderita stroke, beriring jalannya waktu, penderita merasa lebih tenang dan senang dikarenakan ada kebiasaan baru yang membuatnya bangun dari kejenuhan. Seperti, bersuci/tayamum ketika masuk waktu shalat fardlu, melaksanakan shalat lima waktu dengan kondisi duduk, berdoa dan berdzikir setelah melakukan shalat lima waktu. 
Hal ini sesuai dengan teori bahwa dalam tubuh manusia ada sebuah sistem imun yang mempunyai fungsi mengantisipasi serta melindungi diri dari berbagai macam gangguan yang berasal dari dalam tubuh, seperti: patogen (parasit yang bisa menyebabkan timbulnya penyakit), jejas (lecet) dan toksin (zat racun). Sistem imun bisa juga berbentuk kimia, cairan, atau sel (Sholeh, 2007). Spiritual mempunyai relevansi terbesar, sehingga spiritualitas dimasukkan dalam proses pemberian pengobatan untuk meningkatkan kesembuhan pada penderita sakit (Curriera et al., 2019).

Ibadah adalah kebutuhan sangat penting, bukan saja ritual peribadatan tetapi juga mengikuti layanan spiritual, membaca Kitab Suci atau buku-buku tentang Agama, percaya akan adanya sesuatu kekuatan diluar tubuh manusia, dan memiliki seseorang yang selalu mendoakan. Dengan adanya dukungan spiritual yang timbul dari diri sendiri maupun yang berasal dari orangorang disekitar akan menjadikan berfikiran positif, keyakinan akan kekuasaan Tuhan tersebut menjadikan penderita ikhlas dan menerima takdir yang diberikan oleh Tuhan. Ritual keagamaan seperti shalat dan permohonan doa memainkan peranan penting dalam menerima penyakit (Dharma et al., 2020).

Dengan demikian apabila dapat melaksanakan bersuci (tayamum), shalat, doa dan dzikir dengan hati yang tenang, ikhlas dan penuh harap kepada Allah SWT yang dilakukan secara terus menerus, dengan harapan akan menumbuhkan rasa semangat bagi penderita untuk dapat sembuh dari penyakit stroke yang dideritanya. Bahkan bagi individu yang sedang dalam keadaan sehat jasmani, sehingga diharapkan dapat terhindar dari penyakit mematikan tersebut diatas.

Sebagaimana firman Allah SWT dalam Surat Al-An'am ayat 162 yang berbunyi:

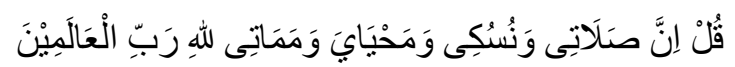

Artinya: Katakanlah Sesungguhnya sembahyangku, ibadatku, hidupku dan matiku hanyalah untuk Allah, Tuhan semesta alam. (Q.S. Al-An'am: 162).

Dengan menempatkan Allah SWT diatas segala-galanya, diharapkan hormon-hormon dalam tubuh bisa bergerak normal dan menjadi tenang. Hal ini menunjukkan adanya peningkatan keimanan yang mempunyai efek bagi tubuh manusia. Seseorang jika shalatnya dilakukan sengan baik maka bisa meningkatkan keimanannya. Ketika terjadi peningkatan keimanan, maka diharapkan manusia bisa selalu posotive thinking (berperasangka baik) jika sudah positive thinking (berperasangka baik), baik dalam mempersepsi hidupnya untuk menjadi lebih baik, walaupun disaat terkena musibah, akan selalu positive thinking.

\section{KESIMPULAN}

Respon spiritual bagi penderita stroke dalam pelaksanaan motivasi spiritual untuk sembuh menunjukan respon spiritual adaptif atau semakin positif dilihat dari beberapa aspek sebagai berikut: memiliki harapan yang realistis (artinya yakin terhadap sakitnya akan sembuh dengan adanya dukungan, perhatian, dan kasih sayang dari keluarga dan orang disekitar), pandai mengambil hikmah (mampu memahami bahwa sakitnya ini bukan hukuman dari Allah tetapi karena bentuk sayang Allah kepada hamba-Nya), dan memiliki ketabahan hati (kemampuan untuk sabar, tabah, dan ikhlas menerima sakitnya).

Motivasi spiritual untuk sembuh pada penderita stroke di Desa Padangsari Majenang Cilacap Jawa Tengah yang diberikan edukasi secara langsung dengan mengunjungi penderita stroke. Upaya yang dapat dilakukan adalah dengan meningkatkan respon spiritual yang baik berupa pemberian semangat motivasi, sugesti, support serta edukasi ibadah selama sakit, seperti: memberikan tuntunan tatacara shalat, tayamum beserta prakteknya, doa dan dzikir secara terus menerus, sehingga penderita menjadi optimis terhadap sakitnya dan mampu memiliki respon spiritual yang baik untuk sembuh. 


\section{DAFTAR PUSTAKA}

A'la, M. A. Z. N. (2017). Penerapan Sholat Tahajud terhadap Penderita Stroke diKlinik Rumah Sehat Avicenna, Desa Tempurejo Kecamatan Pesantren Kota Kediri. Spiritualita: Journal of Ethics and Spirituality, 1(1), 55-68. https://doi.org/https://doi.org/10.30762/spr.v1i1.641

Aprianda, R. (2019). Stroke: Don't Be The One. Retrieved from https://pusdatin.kemkes.go.id/folder/view/01/structure-publikasi-pusdatin-info-datin.html

Curriera, J. M., Fostera, J. D., Witvlietb, C. vanOyen, Abernethyc, A. D., Lunab, L. M. R., Schnitkerd, S. A., ... Carter, J. (2019). Spiritual struggles and mental health outcomes in a spiritually integrated inpatient program. Journal of Affective Disorders, 249, 127-135. https://doi.org/https://doi.org/10.1016/j.jad.2019.02.012

Dharma, K. K., Parellangi, A., \& Rahayu, H. (2020). Religious Spiritual and Psycososial Coping Training (RS-PCT) Meningkatkan Penerimaan Diri dan Efikasi Diri pada Pasien Paska $\begin{array}{llll}\text { Stroke. Jurnal } & \text { Keperawatan 520-533. }\end{array}$ https://doi.org/https://doi.org/10.31539/jks.v3i2.1147

Haia, A. H., Franklina, C., Parkb, S., DiNittoa, D. M., \& Aurelio, N. (2019). The efficacy of spiritual/religious interventions for substance use problems: A systematic review and metaanalysis of randomized controlled trials. Drug and Alcohol Dependence Volume 202, 1 September 2019, Pages 134-148, 202(1), 134-148. Retrieved from https://doi.org/10.1016/j.drugalcdep.2019.04.045

Lazenby, M. (2018). Understanding and Addressing the Religious and Spiritual Needs of Advanced Cancer Patients. Seminars in Oncology Nursing, 34(3), 274-283. https://doi.org/https://doi.org/10.1016/j.soncn.2018.06.008

Lifshitza, M., Elkc, M. van, \& Luhrmann, T. M. (2019). Absorption and spiritual experience: A review of evidence and potential mechanisms. Consciousness and Cognition, 73. Retrieved from https://doi.org/10.1016/j.concog.2019.05.008

Nursalam, K, N. D., Misutarno, \& S, F. K. (2008). Asuhan Keperawatan pada Pasien Terinfeksi HIV/AIDS. Jakarta: Salemba Medika.

Ridho, M. H. (2018). Bimbingan Konseling Spiritual terhadap Pasien Rehabilitasi Napza. Jurnal Studia Insania, 6(1), 036-048. https://doi.org/http://dx.doi.org/10.18592/jsi.v6i1.1914

Satriah, L. (2008). Pendekatan spiritual dalam konseling (konseling spiritual). Irsyad: Jurnal Bimbingan, Penyuluhan, Konseling, Dan Psikoterapi Islam, 1(I), 5-14. Retrieved from https://jurnal.fdk.uinsgd.ac.id/index.php/irsyad/article/view/312

Sholeh, M. (2007). Terapi Sholat Tahajud. Bandung: PT Mizan Publika.

Sitepu, N. F., Asrizal, A., \& Lufthiani, L. (2019). Efektifitas Metode Konseling Spiritual Terhadap Motivasi Pasien Kanker dalam Menjalankan Kemoterapi. Jurnal Perawat Indonesia, 3(3), 175-182. https://doi.org/http://dx.doi.org/10.32584/jpi.v3i3.394 
Styana, Z. D., Nurkhasanah, Y., \& Hidayanti, E. (2016). Bimbingan Rohani Islam dalam Menumbuhkan Respon Spiritual Adaptif bagi Pasien Stroke di Rumah Sakit Islam Jakarta Cempaka Putih. Jurnal Ilmu Dakwah, 36(1), 45-69. https://doi.org/10.21580/jid.v36i1.1625

Sugiyono. (2009). Metode Penelitian Pendidikan: pendekatan Kuantitatif, Kualitatif, dan R\&D. Bandung: Alfabeta.

Suseno, M. N. (2012). Motivasi Spiritual dan Komitmen Afektif pada Karyawan. Jurnal Psikologi, V(1), 31-43. Retrieved from https://www.e-jurnal.com/2015/09/motivasispiritual-dan-komitmen-afektif.html

Tamburian, A. G., Ratag, B. T., \& Nelwan, J. E. (2020). Hubungan antara hipertensi, diabetes melitus dan hiperkolesterolemia dengan kejadian stroke iskemik. Indonesian Journal of Public and Community Medicine (IJPHCM), 1(1), 27-33. Retrieved from https://ejournal.unsrat.ac.id/index.php/ijphcm/article/view/27240

Tanti Suryawantie. (2019). Pemenuhan Kebutuhan Dasar Spiritual pada Pasien Stroke Pasca Akut di Ruangan Cempaka RSUD dr. Slamet Garut Tahun 2019. Jurnal Keperawatan Dirgahayu (JKD), 1(2), 26-31. $\quad$ Retrieved from http://jkd.stikesdirgahayusamarinda.ac.id/index.php/jkd/article/view/70

Umah, K., \& Irawanto, D. (2019). Motivasi Spiritual Meningkatkan Kepatuhan Minum Obat ARV pada Pasien HIV / AIDS ( Spiritual Motivation to Improve ARV Drug Compliance in HIV / AIDS Patients ). Journal of Ners Community, 10(2), 251-263. Retrieved from http://journal.unigres.ac.id/index.php/JNC/article/view/919 